\title{
A Study on the Development and Management of Training Center in Higher Vocational Schools
}

\author{
Jiaqi Mei \\ Jiujiang College, Jiujiang City, Jiangxi Province, P. R. China \\ audiomjq@163.com
}

Keywords: Higher vocational education, training center, combination of school and company, mode

\begin{abstract}
The development of training center is an important way to improve education quality of higher vocational schools. It's an essential condition for human resource training. In the development of training center in higher vocational schools we should follow the idea of combining school and company, corresponding major and industry, teaching and manufacturing, theory and practice, study and career planning together. With the variety of the pattern of development, ways of financing and marketization of operating mechanism of the training center, under the spirit of creativity and practice we may develop various modes of training centers, combine manufacturing, teaching and scientific research in the operating mechanism of training center, and maintain a sustainable development of training centers in higher vocational schools.
\end{abstract}

\section{Introduction}

As part of higher education, higher vocational education is aiming at training qualified technicians, which adapt to the requirements for frontline workers in the field of manufacturing, construction, service and management. These technicians have the characteristics of excellent vocational skills, executive ability, and professionalism. Improving training center is the key of improving the quality of higher vocational the education quality. Training centers help higher vocational schools improve the vocational skills of students and professionalism of their students. With training centers higher vocational schools get the chance to teach their students in an innovative way, improve the students' professionalism in their major. Training centers may also become a highlight of the school and with training centers the school may help the student to find their career orientation, start open mode in school running and combine manufacturing, teaching and scientific research together.

The Ministry of Education of China once made clear in the document "Several Opinions on Improving the Quality of Higher Vocational Education” (EH[2006]No. 6) that improving training center is the key to improve teaching condition, show the highlight of the school and improve teaching quality. Based on the education and market rules, the principle of subject diversification, higher vocational schools should raise money via different ways and in different forms; be connected close to the industries and companies, and make the training centers better and better, search for ways to build a productive training center of schools and achieve new forms of combination between school and company.

Nowadays, improving and managing training centers in higher vocational colleges is an extremely challenging and innovating task. Studying it would help the higher vocational colleges improve their teaching quality and show the highlight in their characteristics.

\section{Basic functions of training center in higher vocational schools}

Training centers are where knowledge is practiced, vocational skills are exercised, scientific researches are used in actual production process and topics in class are studied.

1. Training qualified technicians

Training qualified technicians is the main function of training center. It offers a platform for students to practice what they've learned in school and turn knowledge into their own, and an approach to real working environment. It gives the students the chance to practice and build their own 
professionalism. Training center provides not only advantages to students, but also teachers. Teachers may get qualifications other than teaching in the training center. The training service in training centers is also provided to staff in company and other people out of the school.

2. Manufacturing and providing technical services

As a bridge, training center connect schools to the companies and the society more closely. It works as a platform that school and company, students and teachers in different major and the related industry may communicate with each other. It strengthens the connection among teaching, manufacturing and scientific research; it offer the companies help to solve their technical problems, and at the same time improves the teaching. It combines teaching with the real scientific development and manufacturing, so that teaching becomes more precise, effective and foresighted. In this way teaching, manufacturing and scientific research promote each other. Training center is no longer a project that always takes money, but also profitable, which in the other side could maintain the sustainable development of the training center.

\section{Rules for development of training center in higher vocational schools}

Training centers in higher vocational schools shall focus on the expected qualification of technicians and amount on senior workers or technicians that the industry needs in the coming period of time that as far as we could estimate, help student understand their knowledge and use it in practice and improve the vocational skills and professionalism of the students. The development of training center should have the following characteristics.

1. Reasonable arrangement

Resource in training centers in higher vocational schools should be arranged accordingly in a reasonable way to achieve the purpose of training qualified technicians, follow the innovation of teaching plan and the demand of skill training. The arrangement should follow the education rules, well planned and have clear priority. Training centers shall include labs for proving knowledge, training rooms for practicing skills and workshops with actual manufacturing function for internship. These three function and develop together and achieve the best training result.

2. Similarity to the actual situation

Training center should be as close to the actual situation in factories as possible in the aspect of equipments and working environment, so that the student can get the most precise training they need for their career in the future. In such training centers they could build exactly the vocational skills and professionalism they need and get an insight into knowledge that they learned in school in practice and learn to use it.

\section{Advancement}

The training for students should be foresighted and focus on the characteristics the industry may need in the future, so that the students would be competitive when they really work after graduation. That's the reason why we should equip the training centers with advanced equipments and technology, so that the students can get to know and practice with the latest technique and equipments. Also an advanced management is recommended in the training centers.

\section{Applicability}

The arrangement of training for students in training centers should match the demand of education purpose and follow education rules, so that students can benefit from it. The advanced equipments in the training centers should be suitable for teaching purpose and the training for students should be designed according to the actual situation in high-tech companies and adapt to the rapid development of new technology.

\section{Openness}

The schools need to be open their mind in the development and management of training centers. They should deepen the cooperation between school and company; follow the market rules and principle of variety of development of training center and raise money via different ways and in different forms, to achieve a win-win situation for both schools and companies. The schools may also create or develop more functions for their training centers initiatively, so that the training centers can 
actually provide services to companies or certain industry in the region. In this way training centers of school becomes a window of the school to communicate with companies and provide services, and schools and the companies, the knowledge that is taught in school and the related industry, teaching and manufacturing would be connected close together.

\section{The way to develop and manage training centers in higher vocational schools}

Training centers include training centers on and off campus. Training centers on campus are located inside the school. They simulate actual working environment with modern technology and the condition of actual manufacturing, service \& management of the companies. They're set up for students to practice their vocational skill, which can't be done in classed. Training centers off campus are where students receive training in actual companies. They are supplement for training centers on campus, which may be lack of equipments and space.

The lack of finance support from school is so far the biggest challenge for building a training center of school. To solve this problem, schools need to open their mind and be innovative, and make clear of the development direction of their own training center. They may also search for partners according to the education rules, market rules and the variety of development and develop the training center together; raise money via different ways and in different forms and search for an appropriate way to develop a market-oriented integration of school and company. There're several mode of running a training center in school as follows.

1. Government leading mode

School may strengthen the ability of serving the companies or industry, look for support from education management department and business management department, and try to apply for special fund of major government projects and use this money to develop their own training center, such as the project of development of training center started by the Ministry of Education and the Ministry of Finance, the project of training technicians with high technical ability in the field of national defense, science \& technology and industry, and the development of the relevant training centers started by the Ministry of National Defense and the project of building school labs by both central and local departments and building special labs started by the Ministry of Finance. All these projects have been started since 2004 in the purpose of improving the development of vocational education.

2. School leading mode

School leading mode means the training center is founded by school. These training centers take existed equipments in school and advanced technology as advantage, they are market-oriented and they produce product, run a business and at the same time train the students in school. There're two ways to achieve this mode: School uses its own equipment, technology and management system to develop, manufacture and sell the product; School may also only provide space and equipment, company provides technology, takes the responsibility of management and selling, and arrange manufacturing and training for students.

3. Company leading mode

School can attract support or personnel, finance and material investment from industry or companies through its service for the companies, personnel training for staff in companies and technical support on development on new technique. In return for the investments from companies school can help the companies to promote their image, share the training system with the employees in company and so on. In company leading mode, the company leads both on the manufacturing and the training. School only provides space and management of the training center; the company provides equipments, technique, trainers, and leads both the manufacturing and training of the students.

4. Share mode

Share mode means that both the school and the company run and share the training center of school together. This is a mode with relative higher flexibility in compare with other modes. The school and the company can cooperate in any form based on common demands. Company may 
support the training center with financial investment or equipment. It may also title the training center with the company name.

Training centers of school must build a running system, in which manufacturing, teaching and scientific research unite together, and strengthen the connection among them. The experience in manufacturing and scientific research can be used to improve teaching and make teaching part of the technology and economy development. This is the most important guarantee for a sustainable development of the training centers in higher vocational schools in the knowledge economy era and information technology society.

\section{Summary}

Building a training center is an important part of basic content in teaching for higher vocational schools. It's also a necessary support for training qualified technicians. Training centers shall always cling to the principle that higher vocational education must follow the need from both the market and school, and in training centers the industry or company, corresponding major and industry, teaching and manufacturing, theory and practice, studying and career planning should be combined together. With the purpose of letting the students be part of real product manufacturing while they're in school and gain experience from it before they really work, so that they could build their professionalism, be familiar with their vocational skills through training and get to know some useful vocational skills in practice and become excellent technicians, training centers should concentrate on tracing close to the technology development, creating an environment that is close to the real working environment, improving the students' professionalism and their vocational skills. School may work with company on training center and create reasonable, realistic, foresighted, appropriate and open-minded win-win cooperation for both the school and the company. The training centers of school should also have advanced technology, good environment, various possibility and include the function of teaching, manufacturing, training, vocational skill identification and technical services. Besides, good management will insure that the training centers run well.

\section{References}

[1] Hao Wang, Yuqing Li and Peng Wang: Research and Execution of the Operation Mode of Public Training Center, submitted to journal Occupation (2011).

[2] Yuewen Li and Xinghua Chen: Thoughts concerning the Management of Training Centers in Higher Vocational Schools, submitted to journal Chinese Modern Educational Equipment (2010).

[3] Qian Zhang and Huifeng Zhao: Design and Research of Scene for Teaching in Training Center of School, submitted to journal China Electric Power Education (2010)

[4] Yuewen Li: A Discuss on Training Center in Higher Vocational School, submitted to journal Occupation Education (2008).

[5] Jianrong Xue, Jing Wang and Jun Wang: A Discuss on the Analyze System for Training Center in Higher Vocational School, submitted to the journal Education and Vocation (2007)

[6] Rongfeng Ju, Dunqin Xi and Jianjun Wang: Thoughts concerning the Implement of Joint Stock Structure in Training Center of Higher Vocational School, submitted to journal Chinese Vocational and Technical Education (2001) 